\title{
A vita for Sir George Scharf (GS)
}

\section{George Scharf in his youth}

1816 George Johann Scharf arrives in London, sees people looking at white cakes in shop windows in Piccadilly.

1817 Two paintings by George Sr exhibited for the first time at the Royal Academy.

1820 George Scharf Jr (GS) is born on 16 December to George Scharf Sr and his wife, Elizabeth Hicks, co-owner with her sister of a grocery shop in St Martin's Lane. They married four months before GS's birth.

1830 GS attending University College School with his only brother, Henry, two years younger. Scharf family living at No. 14 Francis Street, near Victoria Station.

1836 Queen Victoria orders three copies of George Sr's drawing of three giraffes displayed at the British Museum.

1839 GS, age nineteen, travels with Sir Charles Fellows to Turkey, stopping on the way in Paris. Sketches Xanthus marbles in situ.

\section{George Scharf in his twenties}

1843 GS goes again with Fellows to Turkey.

1845 GS, age twenty-five, begins his diaries, using a single-volume format.

George Sr returns to Germany, spends two years there with 
a sick brother. Makes the last three paintings he will show at Royal Academy.

1847 Macaulay's Lays of Ancient Rome published with illustrations by GS.

1848 GS with mother, aunt and father (back from Germany) moves to 1 Torrington Square in Bloomsbury, where rent is expensive.

GS gives lectures on art to young ladies at Queen's College, his father providing large-scale illustrations.

1849 GS travels to Rempstone, home of Lady Caroline Sitwell, probably his first visit to a great country house.

\section{George Scharf in his thirties}

1850 GS visits Embley, home of the Nightingales.

1851 GS begins travelling to cathedrals in southern England, making sketches for John Murray's guide.

1852 Election of GS to Society of Antiquaries. Lord Stanhope (then Viscount Mahon) supports his election.

First dinner-party table diagram in GS's diary. Father at head of table, 'I' at foot.

GS giving drawing lessons to ladies, including anatomy.

1853 GS's mother begins keeping a diary. For two years running, every day, she writes just 'bread, milk, ale'.

Brother Henry, an actor, has by now emigrated to the United States.

Scharf family falling behind in payments to tradesmen and shops.

1854 GS applies for position of secretary of the National Gallery, presents recommendations from twenty prominent academics, artists, noblemen, clerics and British Museum administrators; does not get the job.

GS visits Cambridge University, finds his British Museum connections are an advantage there.

Spends Christmas at Rempstone Hall. Promises to sketch tree for his father.

1855 Mother's diary notes once a month 'George had a smoking party'.

Scharf family having increasing difficulty paying their bills.

1856 GS, mother and aunt move to 1 Eastcott Place in Camden 
Town; father moves to separate one-room lodging at 37 Preston Street nearby.

GS designs sets and costumes for Charles Kean's production of The Winter's Tale.

GS travelling with photographer to make images of cathedrals for Murray's Guide. Gives successful lectures in Oxford and Leeds.

GS appointed art secretary to the Manchester Art Treasures Exhibition; begins visiting great country houses to select paintings for exhibit.

1857 GS starts using 'Lett's Professional or Monthly Diary' format. Lord Stanhope appoints GS secretary of the new National Portrait Gallery (NPG) at 29 Great George Street, determines that salary should be liberal and secretary should live on the premises.

GS sketches Florence Nightingale at Embley.

Manchester Art Treasures Exhibition opens, with sixteen thousand works on display, many chosen by GS.

GS moves to apartment over NPG. Mother and aunt come for overnight visits from Camden Town.

1858 GS visits Chevening, Stanhope country estate at Sevenoaks in Kent, for first time.

GS makes first sketching excursion to Knole at Sevenoaks.

Lord Stanhope's professional communications with GS have been impatient and critical. After a trip he and GS make to Canterbury, he is more cordial.

GS retires from Queen's College, gives series of lectures in Birmingham.

1859 Mother's diary reports her servant, Ellen, had been embezzling funds intended for tradesmen. Ellen is dismissed and prosecuted for 'frauds'. Ellen had been with the family since Torrington Square.

George Sr, still living alone, applies to Artists' Amicable Fund for a sick allowance to be added to his pension.

GS frequently visits 'my good friend Miss Bayley' at Wimbledon.

GS produces catalogue of pictures at Blenheim Palace. 


\section{George Scharf in his forties}

1860 Lord Stanhope gives permission for GS's mother and aunt to move into the third-floor space above his apartment at the NPG in Great George Street.

George Sr sells his large watercolours of the ruins of Parliament for only £2 10s.

Henry Scharf returns for a visit from America, where he has worked as an actor and a teacher of anatomical drawing.

GS regularly visiting Chevening and Blenheim.

George Sr in his final illness moves to Great George Street apartment, where he dies.

1861 Charles Dickens comes to NPG for a private viewing.

Prince Albert consults GS about portraits at Windsor Castle. GS, not treated as a guest, has to buy his own refreshment in Windsor that day. GS goes back to Windsor Castle twice that year.

Prince Albert suddenly sickens and dies. GS takes the loss very hard.

1862 First mentions of Jack Pattisson in GS's diary's year-end summary.

Sale of the late George Sr's drawings to British Museum brings in substantial revenue for GS's mother.

1863 GS's list of titled friends expands to include the Duke and Duchess of Marlborough, Lord Bristol, Lord and Lady Darnley and the Archbishop of Canterbury.

1864 Death of GS's Aunt Mary at Great George Street leaves only his mother in the upstairs rooms.

Staying at Chevening, GS receives from Lady Mary (Stanhope's daughter) a pair of slippers she made for him. Jack Pattisson spends almost every evening with GS and his mother above NPG. GS's diary says this 'has done me a great deal of good \& kept me very steadily at home'.

For the first time GS accepts an honorarium for cataloguing a private portrait collection, having asked Lord Stanhope's permission.

GS's mother and Jack's mother exchange visits.

GS's relations with the Stanhopes and Marlboroughs are increasingly friendly.

1865 GS's year-end summary says Jack Pattisson is 'like a brother'. 1866 Pattisson again cited as 'like a brother'. 
1867 GS travels abroad, visiting Paris and making sketches at the Louvre and the World Exposition.

Pattisson's constant presence keeps GS home in the evenings and gives him an unprecedented 'pleasure in home'.

1868 Pattisson and GS often attend theatre and opera together, at GS's expense.

GS dismisses his maid, Anne, for having a man secretly in her bedroom.

GS's mother often ill but cheerful to the end, singing 'old songs' at home in the evenings.

GS's 'dear old friend' Miss Bayley dies at Wimbledon. Leaves GS a $£ 500$ legacy and a piano. GS gives Jack a £25 share.

1869 GS's mother dies. Pattisson and GS are the only two people at her funeral.

GS makes contact with brother, Henry, in America.

GS for the first time invests 'in the public funds', in the amount of $£ 400$.

Jack Pattisson, 'more brotherly than ever', takes a job in Ireland as secretary to Lord Dufferin.

NPG moves from Great George Street to South Kensington. GS takes lodgings at 8 Ashley Place.

GS sends his old piano to Pattisson in Ireland as a gift.

\section{George Scharf in his fifties}

1870 GS stays at Chevening, visits Knole as guest, stays at Blenheim Palace.

GS celebrates fiftieth birthday, thankful for how 'little bodily illness I have known \& how few disappointments of any kind'.

GS's diary reports he has thought of writing to his brother in America, but does not have time.

1871 Pattisson spends much of his summer break at 8 Ashley Place with GS; they attend Freemasons' meetings, plays and operas together.

Scharf dreams of being beheaded, wakes upon remembering he ought to write to his brother Henry.

1872 Pattisson is often home from Ireland, staying with GS at 8 Ashley Place.

Pattisson leaves a message for GS saying he has become engaged. 
Lord Dufferin, now governor of Canada, assigns Jack to a Canadian posting.

GS hosts bachelor party for Pattisson, pays for carriage with footman and postilions to carry Jack, Jack's brother and GS to the wedding.

Pattisson marries Ellen Miller in London, moves with her to Canada.

GS begins 'walking Masonically' in his room late at night to retaliate for loud piano playing downstairs.

1873 Piano Wars continue at Ashley Place.

Nellie Pattisson in Canada is presumed pregnant for nine months, and doctors are puzzled when she produces no baby.

Lady Stanhope dies. GS: 'Another link with my former belongings! Gone!'

1874 GS is initiated as a Freemason, becomes master of his Lodge. Pattisson tries for a new job in London; Lord Dufferin reassigns him to Ireland four years before he is scheduled to leave Canada.

GS shaves for the last time, begins to grow his beard.

GS is ill from October through end of year. Permanent stiffness in left arm and hand are the aftermath.

1875 GS proposes extended visit to Knole, stays several weeks to sketch and arrange pictures.

GS is frequently at Chevening. Lord Stanhope is ill, dies in December. GS has scarlet fever, misses Lord Stanhope's funeral.

1876 GS recuperates at Brighton; he reads Middlemarch and is disappointed by the ending.

Mrs Lee, household servant to GS since 1868, leaves GS's service and 'is heartily tired of it'.

Piano Wars continue at Ashley Place.

GS hires Mr and Mrs Ball and rents modest 'villa' in Vauxhall for them to live in. Before they start work he makes complete inventory of his silver-plate flatware.

GS stays at Chevening, Knole, Blenheim and Bayham Abbey. When at home GS has many dinner guests.

Jack and Nellie Pattisson produce a daughter, Winnie.

GS in October and November makes unusual references to enjoying romps with children at country houses.

Two days before Christmas GS's scullery is swamped with 
water that came in through the roof after a storm. GS: 'It was hard work for Mrs Ball.'

1877 GS begins practising piano at the villa in Vauxhall. The exercise helps with stiffness in his left hand. He also increases frequency of walks in London and is 'not increased in bulk'. GS spends most of the summer at Knole.

Application to NPG for pay raise by GS fails.

The night before an Ashley Place dinner party, GS has a nightmare of being beheaded.

1878 GS spends June at Knole. Goes back in October to find most of the servants have left over a dispute with Lord Sackville. GS advises under-butler to stay on.

GS spends Christmas at Knole.

1879 GS's New Year's entry says, 'My size of body is not less. But I take exercise \& live regularly.'

GS visits Knole. Gives an 'extremely successful dinner' at Ashley Place serving gifts sent from Knole, including venison, chestnuts, gorgonzola and oranges.

GS writes letter to editor of The Times correcting identification of some portraits at the South Kensington NPG.

The Times runs an article on need for bigger space for NPG, praising GS's clever devices for co-ordinating the direction of light with the direction of light in the paintings.

\section{George Scharf in his sixties}

1880 Jack Pattisson becomes private secretary to William $\mathrm{H}$. Smith, first lord of the Admiralty, in London. According to genealogical website he is lodging alone in the home of a telephone clerk.

Freeman 'Donny' O'Donoghue, age thirty-two, on staff at the British Museum, becomes a regular at GS's dinner parties and is often at Ashley Place in the evenings to work on GS's catalogue of brief descriptions of artists.

Piano Wars continue with downstairs neighbour. O'Donoghue falls asleep on the sofa one night despite the noise.

GS takes Donny on excursions to Windsor and Hampton Court.

Pattisson frequently dines 'with us', GS and Donny. Donny now sits at the foot of the table. 
GS notes the death of George Eliot.

GS remonstrates with his servant Mr Ball for inebriety of Mrs Ball, the housekeeper.

1881 Donny constantly at Ashley Place in the evenings. Pattisson and other friends often there for dinner.

GS in pain from loss of teeth; gets fitted for false teeth. Rheumatism in the foot and knee also bother him.

1882 GS promoted from secretary to director of the NPG.

1883 GS dismisses Mr and Mrs Ball after overhearing her using foul language during an argument between them in the kitchen.

GS dreams again of being beheaded.

Times runs an article calling GS 'the most competent living authority on royal portraiture'.

1884 Donny makes a rude remark at dinner, which GS resents.

GS's diary declares Donny 'not a good manager or companion in a crowd'.

1885 GS awarded CB (Companion of the Order of Bath).

Spending Christmas at Chevening, GS becomes ill. His neck becomes stiff, requiring him to hold his head always bent down.

1886 Last card in GS's album collected this year.

GS very ill for over six months, suffering from inflamed gums and a dry cough. He is at first 'quite miserable and could eat nothing'.

GS finds the boardroom at the new NPG site too draughty to be healthy.

'Donny the faithful' still visiting almost every evening, per GS's diary. He is 'very nice \& thoughtful'. Pattisson also visits several times a week during GS's long illness.

Servant Mr Carter disappears on a drinking binge for several days after GS gives him a guinea; GS does not dismiss him.

GS suffers deafness as a result of his long illness. His diary says he cannot hear conversation at table and is "irritable and depressed'.

GS has more teeth removed and replaced with false ones. Frequently he has turpentine poultices applied, which leave painful rashes on his chest.

In July GS takes Donny on a holiday to Margate. They have a cabinet-card portrait taken together.

By year's end GS is feeling well and sleeps comfortably. The 
deafness has abated in the right ear. He is taking long walks in London.

1887 GS's diary says he has 'become fat and old'. Still deaf on the left side, he can hear on the right and can carry on one-on-one conversations. By December he believes he has fully recovered his hearing, but later developments prove otherwise.

At the National Gallery GS runs into the Crown Prince of Germany, who recognises him and reminds him he purchased a GS sketch of a Raphael painting.

GS consults Pattisson on changes to his will.

Donny still constantly there in the evenings.

GS's diary's year-end summary says he now 'enjoys a full sense of comfort, happiness, love of friends, \& I hope also proper contentment'.

1888 Health much improved, GS appreciates continual presence of friends and notes 'Donny still closer'.

Servant Mrs Carter complains loudly of having to wait on Donny as well as GS, because she contracted only to work for 'one family'.

GS still visits Chevening and South Park but finds beds at South Park too soft and has to sleep on sofa in his room.

By year's end GS's 'powers of walking are very limited' and he stoops with 'head thrust forward'.

1889 Philanthropist William Henry Alexander donates the money and the government donates the land in St Martin's Place for the present NPG building, behind the National Gallery at Trafalgar Square.

GS's diary complains of weakness and lassitude but reports improved cheerfulness.

Donny still a constant companion in the evenings, beating GS at cribbage almost every night.

Going to visit Donny in his new lodgings at Clement's Inn, GS gets lost by mistakenly going to Clifford's Inn and has to walk several blocks to find the right place.

One night Mrs Carter serves up delicious strawberries and cream for dessert and, afterwards, anchovies on toast, 'too much both for Donny and me'.

At Chevening in September, GS enjoys sunlight in the garden and writes, 'I have rarely felt a sense of intense beauty \& enjoyment of life as during that half hour.' 
GS notes in year-end summary that he is in debt, but only for small amounts for clothing and piano repair.

\section{George Scharf in his seventies}

1890 GS now has great difficulty walking in London, due to 'very hard breathing'.

GS complains that at an Ashley Place dinner party his friends 'spoke inaudibly'. His deafness increases.

GS still has difficulty with breathing, painful gums and fatigue, but diary reports gratitude that he sleeps so well.

1891 Pattisson, now working at the Treasury and commuting by train from Eastbourne to London, assists GS in making further changes to his will, to the benefit of Donny and three other friends.

GS, now seventy-one and still in his NPG director position, receives from the Treasury a circular about compulsory resignation after age sixty-five. Writes to Lord Hardinge, chair of NPG Board, about it.

1894 GS's diary, now and in previous two years, dominated by daily inventory of physical symptoms and problems with elimination.

When going out, GS orders a carrying chair. Going up and down stairs he must be carried. Donny often assists.

On GS's birthday in December, seven old friends come to dinner. GS notes that Pattisson is abroad until January and cannot come.

For the first time, ladies come to Ashley Place to visit GS in his illness, including the younger Lady Stanhope.

1895 Now GS can only go to the office in a Bath chair and be carried upstairs. This keeps him often at home.

GS still enjoys rich meals at home.

GS is awarded KCB by Queen Victoria. He is now Sir George Scharf. Insignia and dispensation arrive at Ashley Place by mail.

In February Donny's sister dies, and in March his brother dies; Donny's mother has also been ill. GS's diary says Donny is 'terribly pulled down'.

GS can no longer tolerate much company besides his medical attendants, Donny and, occasionally, Pattisson. He is easily fatigued. 


\section{A vita for Sir George Scharf (GS)}

GS retires from directorship of NPG and is replaced by Lionel Cust. GS appointed as an NPG trustee.

Bedridden in great discomfort, GS dies 19 April. His last diary entry is dated 15 April.

1896 NPG moves to new building in St Martin's Square. 
